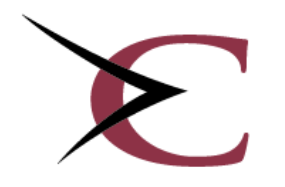

\title{
cirano
}

Allier savoir et décision

2015s-05

The Effect of Job Loss on Health:

Evidence from Biomarkers

Pierre-Carl Michaud, Eileen Crimmins, Michael Hurd 
2015s-05

\section{The Effect of Job Loss on Health: Evidence from Biomarkers}

Pierre-Carl Michaud, Eileen Crimmins, Michael Hurd

\begin{tabular}{c}
\hline Série Scientifique \\
Scientific Series
\end{tabular}

Montréal

Février/February 2015

(C) 2015 Pierre-Carl Michaud, Eileen Crimmins, Michael Hurd. Tous droits réservés. All rights reserved. Reproduction partielle permise avec citation du document source, incluant la notice (C)

Short sections may be quoted without explicit permission, if full credit, including () notice, is given to the source.
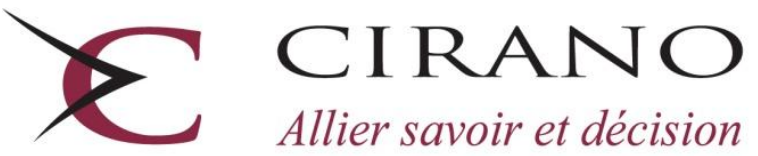

Allier savoir et décision

Centre interuniversitaire de recherche en analyse des organisations 


\section{CIRANO}

Le CIRANO est un organisme sans but lucratif constitué en vertu de la Loi des compagnies du Québec. Le financement de son infrastructure et de ses activités de recherche provient des cotisations de ses organisations-membres, d'une subvention d'infrastructure du Ministère de l'Économie, de l'Innovation et des Exportations, de même que des subventions et mandats obtenus par ses équipes de recherche.

CIRANO is a private non-profit organization incorporated under the Québec Companies Act. Its infrastructure and research activities are funded through fees paid by member organizations, an infrastructure grant from the Ministère de l' l'Économie, de l'Innovation et des Exportations, and grants and research mandates obtained by its research teams.

\section{Les partenaires du CIRANO}

Partenaire majeur

Ministère de l'Économie, de l'Innovation et des Exportations

\section{Partenaires corporatifs}

Autorité des marchés financiers

Banque de développement du Canada

Banque du Canada

Banque Laurentienne du Canada

Banque Nationale du Canada

Bell Canada

BMO Groupe financier

Caisse de dépôt et placement du Québec

Fédération des caisses Desjardins du Québec

Financière Sun Life, Québec

Gaz Métro

Hydro-Québec

Industrie Canada

Intact

Investissements PSP

Ministère des Finances et de l'Économie

Power Corporation du Canada

Rio Tinto Alcan

Ville de Montréal

\section{Partenaires universitaires}

École Polytechnique de Montréal

École de technologie supérieure (ÉTS)

HEC Montréal

Institut national de la recherche scientifique (INRS)

McGill University

Université Concordia

Université de Montréal

Université de Sherbrooke

Université du Québec

Université du Québec à Montréal

Université Laval

Le CIRANO collabore avec de nombreux centres et chaires de recherche universitaires dont on peut consulter la liste sur son site web.

Les cahiers de la série scientifique (CS) visent à rendre accessibles des résultats de recherche effectuée au CIRANO afin de susciter échanges et commentaires. Ces cahiers sont écrits dans le style des publications scientifiques. Les idées et les opinions émises sont sous l'unique responsabilité des auteurs et ne représentent pas nécessairement les positions du CIRANO ou de ses partenaires.

This paper presents research carried out at CIRANO and aims at encouraging discussion and comment. The observations and viewpoints expressed are the sole responsibility of the authors. They do not necessarily represent positions of CIRANO or its partners.

ISSN 2292-0838 (en ligne) 


\title{
The Effect of Job Loss on Health: Evidence from Biomarkers"
}

\author{
Pierre-Carl Michaud ${ }^{\dagger}$,Eileen Crimmins ${ }^{t}$, Michael Hurd ${ }^{\S}$
}

\begin{abstract}
Résumé/abstract
The effect of job loss on health may play an important role in the development of the SEShealth gradient. In this paper, we estimate the effect of job loss on objective measures of physiological dysregulation using longitudinal data from the Health and Retirement Study and biomarker measures collected in 2006 and 2008. We use a variety of econometric methods to account for selection and reverse causality. Distinguishing between layoffs and business closures, we find no evidence that business closures lead to worse health outcomes. We also find no evidence that biomarker health measures predict subsequent job loss becaue of business closures. We do find evidence that layoffs lead to diminished health. Although this finding appears to be robust to confounders, we find that reverse causality tends to bias downward our estimates. Matching estimates, which account for self-reported health conditions prior to the layoff and subjective job loss expectations, suggest even stronger estimates of the effect of layoffs on health as measured from biomarkers, in particular for glycosylated hemoglobin (HbA1c) and C-reactive protein (CRP). Overall, we estimate that a layoff could increase annual mortality rates by $9.4 \%$, which is consistent with other evidence of the effect of mass layoffs on mortality.
\end{abstract}

Mots clés /Key words : Job loss, Health, SES-health gradient, Biomarkers.

Codes JEL : I14, J10, J14.

\footnotetext{
${ }^{*}$ This research was supported by the National Institute on Aging, under grant R01AG040176. We thank David Boisclair, Nancy Campbell, Francois Laliberte-Auger and Clifford Grammich for excellent research assistance. We thank Fabian Lange, Italo Guttierez and seminar participants at McGill University. Errors are our own. ${ }^{\dagger}$ Industrielle Alliance Research Chair on the Economics of Demographic Change, ESG UQAM, CIRANO, IZA and \& RAND; michaud.pierre_carl@uqam.ca .

AARP Professor of Gerontology, Davis School of Gerontology, University of Southern California; crimmin@usc.edu

${ }^{\S}$ RAND Corporation and NBER; mhurd@rand.org
} 


\section{Introduction}

The SES-health gradient expands over the working years (e.g. Smith, 1999). Both health and SES shocks can increase the gradient. Health shocks may lead to reduced earnings resulting from prolonged absence from the labor force and in turn lead to lower SES. Similarly SES shocks such as job loss may lead to worse health given financial strain associated with these events. This could occur either because of stress or simply because job loss makes it hard to access health care (e.g. for example due to lack of insurance). Through these different mechanisms, economic instability may be a powerful driver of the expansion of the SES-health gradient over the working years.

Job loss is typically associated with significant financial consequences (Moen, 1983), with financial strain resulting in stress (Voydanoff, 1984). Financial strain has been found to be strongly associated with psychological distress among the unemployed (Kessler, Turner and House, 1987). Blake (1995) finds that stress is greater when job loss occurs in a region with low unemployment levels. Several studies have found that job loss is followed by poorer health outcomes (Catalano and Dooley, 1983; Montgomery, Cook, Bartley and Wadsworth, 1999).

There are two concerns with interpreting this evidence as causal. First, omitted unobserved variables may bias causal inference. These confounders may be both related to the incidence of job loss as well as health. The long-reach of SES and health earlier in life may significantly impact events later in life. Second, reverse causality (effect of health status on job loss) may also bias causal estimates. For example, employers may layoff sicker workers first since health is correlated with absenteeism and productivity. For this reason, some studies have focused on the long-term effects of job displacement on mortality and a range of other health-related outcomes using more exogenous sources of job loss such as business closures or mass layoffs.

For example, Sullivan and von Wachter (2009) find that displaced workers in Pennsylvannia faced a 10-15\% increase in mortality rates compared to other workers twenty years after job displacement. These effects are large and raise the question of how, when, and 
where they occur. Strully (2009) finds the quasi-experimental evidence using particular plant closures focuses on manufacturing jobs and with results that may not be generalized. Her work using three waves of the Panel Study of Income Dynamics finds statistically significant effects of "no-fault" job loss (mostly business closure) on self-reported health and select health conditions but includes few health controls to account for reverse causality. Schroder (2013) found mixed negative long-term effects of layoffs and business closure on self-reported health outcomes at older ages for a number of European countries, with the largest effects occurring for females. Using self-reported health measures such as being diagnosed by a doctor may be problematic because diagnostics themselves may be endogenous to job loss. Hence, job loss may not affect health directly but increase the likelihood of being diagnosed. Some studies find no effect of job loss on health, in particular when looking at short-run effects of job displacement due to business closure on self-reported health (e.g. Salm, 2009) and hospital visits (Browning et al., 2006). Short-run effects, however, may not be evident in increased self-reported doctor diagnosis or hospital visits.

Long-run effects of job loss on health may be important with better markers of health needed to detect them. Theories based on biological processes suggest a link from economic instability to stress and health (Sterling and Eyer, 1988; McEwen and Stellar, 1993). These postulate that experiencing frequent or prolonged episodes of stress can lead to wear and tear on the body, disrupting regulatory systems and ultimately worsening health. These theories emphasize allostatic load or physiological dysregulation as the mechanisms by which stressful events lead to worse health outcomes in the long term. Several studies provide evidence of the mediating role of physiological dysregulation between stresses associated with low socioeconomic status, poor work conditions including job demands, and future mortality (Seeman, Burton et al. 1997; Schnorpfeil et al, 2003; Seeman, Crimmins et al. 2004; Seeman, Merkin et al. 2008). While there are multiple approaches to measuring physiological dysregulation, one common method is to use the count of biomarkers beyond levels of clinical risk.

In this paper, we exploit the rich longitudinal content of the Health and Retirement Study (HRS) along with biomarker and anthropometric measures collected in 2006 and 2006 to 
investigate the relationship between job loss and "objective" measures of health. Because of its longitudinal design, we are able to construct measures of exposure to job loss, distinguishing between layoffs and business closures. We consider an exposure period ranging from 2 to 14 years. This allows us to assess medium-term effects on a wide range of self-reported and objective (e.g., biomarker) health measures. Because we have access to a rich set of controls, including measures of childhood health and SES, we are able to assess the effects of confounders. Because we also have data on an extensive set of health measures prior to job loss, as well as job loss expectations for a subset of waves, we investigate the potential for reverse causality to bias inference. We use a matching estimator which allows us to match those who experience and do not experience job loss on a large set of characteristics, including self-reported health measures.

In section 2, we present the data and the construction of the variables used. In Section 3, we present the methods used. In Section 4, we present our results. We offer conclusions and note limitations in section 5 .

\section{Data}

\subsection{Biomarkers and Anthropometric in the HRS}

As noted, we draw our data from the HRS, a biennial panel survey of U.S. adults at least 50 years of age. In 2006, the HRS began collecting blood spots, saliva, and anthropometric measures as part of enhanced face-to-face interviews. Half the respondents (who responded for themselves and were not institutionalized) were randomly selected in 2006 to participate in this additional data collection in 2006, with the remaining half asked to participate in 2008. Altogether, HRS files with biomarkers contain 13,064 respondents. Details on the protocols for collection and assay of the biomarkerd data are found in the documentation on the HRS website (Crimmins et al., 2013). The available blood-based bio-marker measures include glycosylated hemoglobin (HbA1c), C-reactive protein (CRP), high density lipoprotein (HDL), total cholesterol, and Cystatin C. We also include measures of diastolic and systolic 
blood pressure and pulse.

Because of the retrospective nature of our study, we use data from two cohorts in the Health and Retirement Study. First, we use the Health and Retirement Study cohort (born 1931-1941) with respondents who were 51 to 61 years old at first interview in 1992 and 65 to 77 years old in 2006/2008. . Second, we select War Babies cohort respondents (born 1942-1947) who entered in 1998 at the age of 51-56 years old and were 59 to 66 years old in 2006/2008. Across these two cohorts, 3,562 respondents have complete biomarker information and non-missing information on important covariates for regression analysis and were between 59 and 70 years of age in 2006-2008. For these respondents, we can observe 8 to 16 years of job history. We drop older respondents because they have shorter work histories in the data and were therefore less likely to be exposed to job loss and because survival bias which could lead to self-selection of healthier respondents. ${ }^{1}$ Table A.1 in the appendix gives details on observations lost due to sample selection and missing covariates. We used sample weights in our analysis.

To measure objective health, we create a set of 10 high-risk indicators using the biomarker and anthropometric measures collected. We use the indicators and thresholds reported in Crimmins et al. (2010). These are largely based on medical guidelines. Table 1 reports the list of indicators, the risk threshold indicators for each, and the fraction of respondents with levels at high risk.

\section{[Insert Table 1 Here]}

Nearly $15 \%$ of respondents have high HbA1c, a measure of average blood glucose level over the past few months. Nearly $21 \%$ reported a doctor's diagnosis of diabetes. More than $8 \%$ of respondents have been diagnosed but have their A1c under control (below $6.4 \%$ ). In comparison, 3.6\% have not been diagnosed by a doctor but have elevated HbA1c. More than $8 \%$ of the sample who have been diagnosed by a doctor as having diabetes have their HbA1c under control. Close to $40 \%$ of respondents have elevated levels of C-reactive protein,

\footnotetext{
${ }^{1}$ The HRS has a retrospective job history survey but in preliminary analysis we found indications of recall bias and considerable heaping. We therefore decided to focus on the observed work history in panel.
} 
a measure of general inflammation in the body which has been associated with elevated risk of diabetes, hypertension and cardiovascular disease. A smaller fraction of the sample, $5.8 \%$, has high Cystatin C, a measure of poor kidney function. Regarding cholesterol levels, $20.7 \%$ have high total cholesterol, 13.6\% low total cholesterol, and 19.8\% low HDL cholesterol. Regarding blood pressure, $19.2 \%$ have high diastolic blood pressure and $28.9 \%$ have high systolic blood pressure while $2.4 \%$ have low diastolic blood pressure. A total of $33 \%$ have either high diastolic or systolic blood pressure. A total of $53 \%$ of respondents have been diagnosed with high-blood pressure, while $33 \%$ have been diagnosed for hypertension but have it under control while $11.7 \%$ appear to be undiagnosed. Finally, only $6 \%$ of respondents have elevated pulse.

For each respondent, we sum the number of high risk markers. This yields an objective measure of health which ranges in our sample from zero to 8 (theoretically could go to 10). Figure 1 shows the distribution of our measure for two-year age groups.

\section{[Insert Figure 1 Here]}

We observe a general increase in the number of risk markers over a relatively short age span. Fewer than one in five (19.5\%) respondents have no high-risk markers, while one in four $(24.4 \%)$ have more than 2 high-risk markers. Since the HRS provides mortality tracking, we compute mortality rates in the two years following biomarker collection. Those with no high-risk markers have a 2-year mortality rate of 0.011 , those with one have a 0.021 rate, those with two have a 0.030 rate, those with three have a 0.041 and those with four or more have a two-year mortality rate of 0.078. In other words, those with four high-risk markers have two-year mortality rates 7.1 times as great as those with none, making these measures of health an important predictor of mortality.

\subsection{Job Loss and Job Characteristics}

For each of the respondents with valid biomarker and anthropometric measures, the HRS has information for each job termination and the reason for termination during the observation period. Two choices are particularly relevant for this research. First, respondents can report 
a job termination due to a layoff. Second, they can report a job termination due to a business closing. Because both these choices were available, we construct an indicator variable taking the value 1 if the event occurred during the observation period. Few respondents were laid off twice or lost jobs because of multiple business closings during the observation period. Overall, 16.9\% were ever laid off while $8.8 \%$ lost their job because of business closure. Only $138(2.61 \%)$ had both occur during the observation period.

Because job loss varies by occupation and industry, we also construct a dummy variable indicating whether the longest-held job was in a manual occupation, as well as a variable indicating whether it was in a primary (e.g. mining), secondary (e.g. manufacturing), or tertiary industry (e.g. services).

\subsection{Childhood, Family History and Parent Characteristics}

Because health differences may originate earlier in life, we construct variables for childhood and family environment of each respondent. In addition to providing good controls for confounders in regression analysis, potential associations with health later in the life-cycle are also interesting. The HRS contains a battery of questions on the childhood environment. For more than half the respondents, the mother worked during childhood. In more than $71.2 \%$ of cases, at least one parent smoked when they were a child. On average, mothers had 10.3 years of education compared to 9.9 for fathers.

The HRS collects information on childhood health. $80.6 \%$ considered their health as very good or excellent at age 16. Prior to age 16, respondents had an average of 1.41 infections (measles, mumps or chicken pox) and an average of 0.35 out of the following 15 health conditions (vision problems, asthma, diabetes, respiratory problems, speech problems, allergy, heart trouble, ear problems, epilepsy, headache, stomach problems, high blood pressure, depression, drug problems, psychological problem). We define indicator variables for those with missing information on these covariates and use them as controls in regression analyses.

We create variables which record the number of times the respondent was ever married, the number of children the respondent had, and the respondent's age when the first child was 
born. On average, respondents had 1.41 marriages, with 2.50 children and an average age at first birth of 24.2 .

\subsection{Other Variables from Core HRS}

We construct a series of background characteristics from the Core Survey of the HRS. The average age is 64 years old, $9.1 \%$ of respondents are black, $6.9 \%$ hispanic and $47 \%$ male. We recode the education variable in three groups (less than high school, high school and college). We drop cases with missing observations on these variables.

We construct a series of prevalence variables for diabetes, hypertension, heart disease, stroke, cancer, and lung disease. These will be used as alternative-outcome variables in the analysis as well as controls to match respondents based on health prior to job loss. More than half the respondents report they have hypertension, $20.6 \%$ have heart disease, $13.5 \%$ cancer, $6.3 \%$ stroke, $18.6 \%$ diabetes, and $9.8 \%$ have lung disease.

\section{Methods}

Denote by $n_{i}$ the count of risk markers taken either in 2006 or 2008 . Let $z_{i}$ be an indicator variable for the occurrence of either a layoff or business closure since the first interview. Let also $x_{i}$ be a vector of socio-economic characteristics at the time of interview and $w_{i}$ be a vector of childhood and life history variables. We postulate that $n_{i}$ conditional on $\left(z_{i}, x_{i}, w_{i}\right)$ is distributed poisson, with conditional expectation:

$$
E\left[n_{i} \mid z_{i}, x_{i}, w_{i}\right]=\exp \left(z_{i} \gamma+x_{i} \beta+w_{i} \psi\right)
$$

This assumes that $z_{i}$ is independent of unobservables conditional on $\left(x_{i}, w_{i}\right)$. There are two considerations that may invalidate this assumption. First, some confounders may have been omitted from the controls. We will address this issue by using an extensive set of controls and varying that set across specifications. To the extent that effects are similar across sets 
of controls, omitted confounders are unlikely to significantly alter the results. The second is reverse causality. One's health status may lead to job loss rather than job loss leading to poor health. To test for this possibility, we will use data on job loss subsequent to measurement of biomarkers to estimate a model predicting job loss based on poor health. Hence, we will estimate a logit model of the type

$$
\operatorname{Pr}\left[z_{i, t+1}=1 \mid x_{i}, w_{i}, n_{i}\right]=\Lambda\left(x_{i} \alpha_{x}+w_{i} \alpha_{w}+n_{i} \alpha_{h}\right)
$$

where $\Lambda()$ is the logistic distribution function. A test of reverse causality can be implemented by examining whether $\alpha_{h}=0$. If we reject the null hypothesis, reverse causality may be a concern. To address this concern, we will use a matching estimator. For each job loss, we know the termination date of the job. Hence, we have information on health status of the respondent from the interview prior to job loss. Let the vector of health status variable be $h_{i}$. For each treated respondent with job loss in wave $s$, we can find a comparable respondent with similar characteristics $q_{i, s}=\left(h_{i, s-1}, x_{i}, w_{i}\right)$. We add to the set of controls whether the respondent is working in $s-1$. We estimate for each wave $s$, a logit model predicting job loss in wave $s$ as a function of $q_{i, s}$. Let $p_{s}\left(q_{i, s}\right)$ be the predicted job loss probability of someone with characteristics $q_{i, s}$. We use the nearest neighbor of each respondent based on this propensity score $p_{s}\left(q_{i, s}\right)$. Let $r(i, j)=1$ if observation $j$ is the nearest neighbour of observation $i$ and zero otherwise $\left(j=\min _{j}\left|p_{s}\left(q_{i, s}\right)-p_{s}\left(q_{j, s}\right)\right|\right)$. Then the matching estimator of the effect of job loss on $n_{i}$ is given by

$$
\Delta_{z}=\frac{1}{N_{z}} \sum_{i: z_{i}=1}\left(n_{i}-\sum_{j: z_{j}=0} r(i, j) n_{j}\right)
$$

where $N_{z}$ is the number of respondents with a job loss. Standard errors are computed using Abadie and Imbens (2006) and bias-correction is implemented following Imbens and Abadie (2011). 


\section{Results}

\subsection{Health and Job Loss}

In Table 2, we report differences in health by the type of job loss respondents experienced since the first interview. We do this for the count of risk markers $\left(n_{i}\right)$ as well as for each marker separately. We also report differences using self-reported health conditions in 2006/2008.

[Insert Table 2 Here]

The count of high risk markers is statistically significantly higher among those who experienced layoffs (diff $=0.137, \mathrm{t}=2.34$ ) but not among those who experienced a business closure (diff $=0.089, \mathrm{t}=1.143)$. For layoffs, disaggregation shows no significant differences in biomarkers between those who experienced job loss and those who did not. Only self-reported hypertension is statistically significant at the $10 \%$ level. The difference for Cystatin-C is negative, indicating higher level among those who did not experience a layoff. Those with layoffs did not experience a higher mortality in the subsequent two years. For those who experienced a business closure, no risk marker had notable differences. This is also true for self-reported health conditions and mortality.

\subsection{Characteristics of Respondents with Job Loss}

Differences reported in Table 2 are subject to important confounders which include general socio-economic status as well as initial (childhood) health differences. Those may differ importantly between those who suffered a job loss and those who did not. We report in Table 3 the distribution of some of the characteristics for those who experienced a layoff or a business closure compared to those who did not.

[Insert Table 3 Here]

As may be expected, those who had a layoff were older, less likely to be black, and more likely to be in a secondary than a tertiary industry. Overall differences in characteristics, even where statistically significant, are not large for this group. 
Differences for those who experienced a business closure are more pronounced. In particular, they are likely to be older, to be less educated, to be Hispanic, and to have had a working mother with less education. Most importantly, respondents who experienced a business closure are more likely to be in a manual occupation in the secondary sector of the economy. This could be explained by the fact that business closures have been more pronounced in this sector than in other sectors during the last 20 years.

\subsection{Poisson Models}

We first consider the count of high-risk markers using poisson models. The poisson specification imposes the strong assumption of equi-dispersion (variance equals mean). We tested for over-dispersion and could not reject the null hypothesis of equi-dispersion. Hence, we report poisson estimates. The parameters reported are the average marginal effects. Table 4 reports the results of four specifications where we vary the set of confounders.

\section{[Insert Table 4 Here]}

If we focus on layoffs and business closure, we see an unambiguous positive association between layoff and the count of high-risk biomarkers but suggestion of a negative association for business closure. The effect for layoff is relatively large (in column 4, marginal effect(me) $=0.167$, se $=0.058)$. Its magnitude is similar to that of male-female differences.

As noted, we can detect only a negative association between the incidence of business closure and the count of high-risk markers. The point estimates are relatively stable across specifications. Of the covariates we vary, we found only father's education, some childhood health variables, and the number of one's children to have an association with the count of high-risk markers. Father's education appears to reduce while the number of children increase the number of high-risk markers. The largest differences are found between college and high school dropouts (in column $4, \mathrm{me}=0.391$, se $=0.0888$ ). These large differences in terms of education highlight that socio-economic status is an important determinant of health differences. 
The marginal effect for both layoffs and business closure are highly stable across specifications. Nevertheless, there is the potential for other confounders to bias estimates. In Table 5, we repeat the specification in column 4 of Table 4 adding current household income and net wealth (column 2). Of course, this is likely to lead to over controlling given that layoffs and business closure may have an effect on health through income and wealth. Yet adding these controls does not much change the observed effects of layoff and business closure. Both household income and wealth have small effects in this model, with those for income being statistically insignificant as well. This finding supports our contention that the differences in effects of layoffs and business closure on health are not purely driven by differences in socio-economic status. The third column selects only respondents who were working at first interview. Including both those who are retired by the time we measure biomarkers and those who remain at work could bias inference. In the model including only respondents working at first interview, the marginal effect for layoffs on count of risk markers increases to 0.195 $(\mathrm{se}=0.0670)$.

\section{[Insert Table 5 Here]}

In the last column, we estimate a poisson model where the dependent variable is the count of self-reported health conditions in $2006 / 2008$. Here, the effect of layoffs on health becomes statistically insignificant, while the negative effect of business closures on health becomes statistically significant. This pattern is consistent with the likely effect that the loss of health insurance would have on the ability of respondents to receive diagnoses. At the same time, loss of job would not affect biomarker indicators gathered by the HRS.

We also tested whether effects vary by time since the layoff or business closure occurred. Allowing for wave-specific effects, we cannot reject the null hypothesis that effects are constant with exposure. This suggests that effects are long-lasting ( $\mathrm{p}$-value $=0.4853$ for layoffs and $\mathrm{p}$-value $=0.7956$ for business closures). ${ }^{2}$

A good comparison to assess the magnitude of the effect found is to look at the induced effect on mortality. Because our sample of workers experiencing layoffs is already small and an

\footnotetext{
${ }^{2}$ Results available upon request.
} 
even smaller group dies within 2 years after biomarker collection, it is not possible to detect direct effects of layoffs on mortality. We can, however, compute the effect of a layoff on the count of biomarkers and then use a mortality regression on age, socio-economic characteristics, and the count of high-risk markers to get an idea of the magnitudes. When we do this, we find that a layoff increases annual mortality risk by $9.4 \%$. This effect is large but in line with results reported by Sullivan and von Wachter (2009), who found job displacement to increase annual mortality risk by $10-15 \%$.

\subsection{Reverse Causality}

One potential bias in our multivariate regressions is reverse causality. Health events prior to job loss may trigger job loss and be correlated with future health. To test for this possibility, we estimate a logit model for the probability of losing a job in 2008/2009 for respondents who were employed at the time of biomarker record collection. We control for the same confounders as in Table 4 and add controls for health in 2006/2008. In Table 6, we report marginal effects for different health variables.

[Insert Table 6 Here]

When using the count of risk markers, we find evidence of reverse causality for layoffs but of the unexpected sign. Specifically, we found those with a higher count of risk markers were less likely to subsequently experience a layoff. This result is unaffected if we focus on respondents who remain at work in the next wave. We find no effect of self-reported health conditions on subsequent employment. To the extent that employers observe employee health, it is surprising that these variables do not predict layoffs. We find no evidence regarding reverse causality for business-closure job loss, that is, we do not find that health conditions affect subsequent job loss from business closure. 


\subsection{Matching}

Because there is some (albeit negative) evidence of reverse causality for health and layoff job loss, we adopt the matching estimator suggested earlier to control for health prior to job loss. The quality of the match can be assessed using estimates of the matching standard bias which is a measure of how different means of the different variables used to match are different in the treatment and matched-control samples. Table A.2 in the appendix reports estimates of match standard bias. Unmatched differences are large for a number of variables, often exceeding 10 percent. The matched-control means are much closer and larger deviations exist only for a handful of covariates (occupation and industry). Overall, the matched control sample appears to be very similar to the treated sample (those with job loss). Table 7 reports matching estimates of the effect of job loss on health.

[Insert Table 7 Here]

Even after controlling for prior health, the effect of layoff on the count of risk markers remains and is even slightly stronger than suggested by poisson models ( $\mathrm{pe}=0.2366$, se $=$ 0.0773). The effect for business-closure termination remains statistically insignificant and mostly negative. Hence, consistent with our evidence on reverse causality, our estimates of layoff on health which correct for baseline health are larger.

Turning to individual markers, three key markers are statistically significant: HbA1c, CRP, and low total cholesterol. The effect on CRP is interesting because it is a general marker of inflammation. According to the theory of physiological dysregulation, it is one of the mechanisms by which stress may affect long-term health. We find a relatively large effect. The fraction of respondents in our analysis sample with high CRP is $39.6 \%$. An increase of 7 percentage points in the prevalence of high CRP is non-trivial.

Effects of business closure remain small and statistically insignificant in the model for Table 7. Across all our different specifications, we could not detect any evidence of a positive relationship between business-closure job loss and subsequent biomarker measurements. 


\subsection{Job Loss Expectations}

One concern with these estimates is that some workers may anticipate layoffs (in particular mass layoffs) and leave their job prior to the event. This could bias results depending on who leaves or changes employment. Fortunately, the HRS collects information on job-loss expectations. Each worker is asked for the probability that he may lose his job in the near future. In order to assess the effect of expectations on our estimates, we repeat the matching exercise adding job-loss expectations in the wave prior to the layoff to our control variables. Although the samples are not exactly identical because the question was not asked in some waves, we find evidence that the results are virtually unchanged once we add expectations to our control variables. ${ }^{3}$

\subsection{Health Care Use}

One possible channel for job loss to affect health is through the loss of health insurance. To investigate this issue, we re-run the poisson model in Table 4 (last column) and include as a regressor whether the layoff or business closure occurred on a job where the worker had health insurance. We consider workers who did not have health insurance on the job separately from others. In results we do not report here, we found no difference in the effect of layoff on health across these two types of workers. Hence, the effect of job loss on health is not due to the loss of health-insurance coverage.

We can also investigate whether those with a layoff or business closure use more health care. To do so, we consider the number of doctor visits and hospital nights as well as medication use for respondents in 2006/2008. We use the matching estimator developed earlier to look at the effect of job loss. Results are reported in Table 8.

\section{[Insert Table 8 Here]}

Overall, there is little effect of job loss on health-care use. One exception is the number of doctor visits by those who experienced a layoff. We find that such respondents increased

\footnotetext{
${ }^{3}$ Results available upon request.
} 
their number of doctor visits by 1.4577 on average in the subsequent two years. The average number of doctor visits in the last two years is 9.4 in the sample. Given that we found direct effects on health as well as no effect of insurance on health, one could argue that this increase truly reflects an increased demand for health services.

\subsection{Health Behaviors}

We find effects of layoffs on HbA1c and CRP levels. One possibility for this result is that the effects run through health behaviors such as smoking and eating or exercise habits. Yet when examining body-mass index (BMI) and smoking status at the time of biomarker collection, we do not find evidence of any relationship between these behaviors and prior layoffs. We also considered a measure of change in BMI since baseline and did not find effects for that variable either. ${ }^{4}$

\section{Discussion}

The expansion of the health-SES gradient during working life is likely the result of health and SES shocks. A key SES shock that may occur over someone's life is job loss, either through a layoff or a business closure. In this paper, we investigate this relationship using biomarker data on a sample of respondents aged 59-70 for whom we have detailed job history going back 8 to 16 years.

Our results are fourfold. First, we find no relationship between business closures and health, either measured using biomarkers or self-reported health. This finding is robust to varying sets of controls and reverse causality. Second, we find a robust effect of layoffs on health, measured using biomarkers. Third, although there is evidence of reverse causality, matching estimates, which account for baseline self-reported health, corroborate estimates from poisson regressions and are even larger. Finally, these effects on health translate into an increased occurrence of doctor visits for those with layoffs.

\footnotetext{
${ }^{4}$ Results available upon request
} 
We see no difference in the estimated effect of layoffs by whether the worker did or did not have health insurance on the job. The effect is also not due to differences in income or wealth following job loss because controlling for those did not alter the relationship between layoffs and health. These results match those of previous studies linking job loss to long-term mortality (e.g. Sullivan and von Wachter, 2009).

Our results suggest specific long-term effects on HbA1c and C-reactive protein. The latter marker, which is associated with inflammation, is a predictor of a number of chronic health events. Because of sample size, we are not able to detect effects on mortality. However, using our estimates, we can back out the effect of annual mortality rates. We find that our estimates could explain a $9.4 \%$ increase in annual mortality rates in the long run. This compares well to estimates obtained by Sullivan and von Wachter (2009).

Our analysis does have limitations. First, sample size and the fact that both job loss and some risk markers are relatively rare may imply that our study is underpowered. Second, job loss is self-reported, which implies that it could be measured with error. Third, we had a measurement of biomarkers at a single point in time. In particular, it was not possible to obtain measures of biomarkers prior to job loss. Finally, our sampling frame and the quality of retrospective data implied that we could not investigate job loss prior to the first interview, leading us to focus on job loss after the age of 50. Hence, results are not necessarily generalizable to the entire age range.

Despite these limitations, our results suggest that layoffs and business closure may have truly distinct effects on health. One conjecture for this is that layoffs are more personal and resulting negative perception of the worker about his own ability as well as social stigma might lead to worse health outcomes. One mechanism for this result may be through physiological dysregulation and in particular inflammation. Our disaggregated results point to increased CRP among those who experienced layoffs and implies increased mortality risk. 


\section{References}

Abadie, Alberto, and Guido W. Imbens. "Large Sample Properties of Matching Estimators for Average Treatment Effects." Econometrica 74, no. 1 (January 1, 2006): 235-67. doi:10.1111/j.1468-0262.2006.00655.x.

Blake, T. (1995): "Economic Context and the Health Effects of Unemployment", Journal of Health and Social Behavior, 36:3, p.213-230.

Browning, Martin, Anne Moller Dano, and Eskil Heinesen. "Job Displacement and Stressrelated Health Outcomes." Health Economics 15, no. 10 (October 2006): 1061-1075. doi:10.1002/hec.1101.

Catalano R, Dooley D. "Health Effects of Economic Instability: A Test of Economic Stress Hypothesis" Journal of Health and Social Behavior. 1983;24:46-60.

Crimmins, Eileen, Jung Ki Kim, and Sarinnapha Vasunilashorn. "Biodemography: New Approaches to Understanding Trends and Differences in Population Health and Mortality." Demography 47 Suppl (2010): S41-64.

Crimmins, Eileen, Jessica Faul, Jung Ki Kim, et al. 2013. "Documentation of Biomarkers in the 2006 and 2008: Heath and Retirement Study." Survey Research Center, University of Michigan. Ann Arbor, MI.

Imbens, Guido, and Alberto Abadie. "Bias-Corrected Matching Estimators for Average Treatment Effects." Journal of Business and Economic Statistics 29, no. 1 (2011): 1-11.

Kessler, Ronald C., J. Blake Turner, and James S. House. 1987. "Intervening Processes in the Relationship between Unemployment and Health." Psychological Medicine 17:949-61.

McEwen, B. S. and E. Stellar (1993). "Stress and the individual. Mechanisms leading to disease." Arch Intern Med 153(18): 2093-2101

Moen, Phyllis. 1983. "Unemployment, Public Policy, and Families: Forecasts for the 1980s." Journal of Marriage and the Family 45:751-60.

Montgomery, S.M., Cook, D.G., Bartley, M.J. and M.E. Wadsworth (1999). "Unemployment pre-dates symptoms of depression and anxiety resulting in medical consultation in young men." International Journal of Epidemiology, 28:1, 95-100.

Rosengren A, Hawken S, Ounpuu S, Sliwa K, Zubaid M, Almahmeed WA, et al. "Association of psychosocial risk factors with risk of acute myocardial infarction in 11119 cases and 13 648 controls from 52 countries (the INTERHEART study): case-control study." Lancet 2004; 364: 953-62.

Salm, M. (2009): "Does Job Loss Cause Ill Health", Health Economics, 18, pp. 1075-1089.

Schnorpfeil P, Noll A, Schulze R, Ehlert U, Frey K, Fischer JE. (2003): "Allostatic load and work conditions" Social Science and Medicine, 57, pp.647-56. 
Schroder, Mathis. "Jobless Now, Sick Later? Investigating the Long-term Consequences of Involuntary Job Loss on Health." SHARELIFE - One Century of Life Histories in Europe 18, no. 1 (March 2013): 5-15. doi:10.1016/j.alcr.2012.08.001.

Seeman, T. E., S. H. Burton, et al. (1997). "Price of Adaptation - Allostatic Load and Its Health Consequences: MacArthur Studies of Successful Aging." Archives of Internal Medicine 157.

Seeman, T. E., E. Crimmins, et al. (2004). "Cumulative biological risk and socio-economic differences in mortality: MacArthur Studies of Successful Aging." Social Science \& Medicine 58: $1985-1997$.

Seeman, T. E., S. S. Merkin, et al. (2008). "Education, income and ethnic differences in cumulative biological risk profiles in a national sample of US adults: NHANES III (19881994)." Social Science \& Medicine 66: 72-87.

Smith, James. "Healthy Bodies and Thick Wallets: The Dual Relation Between Health and Wealth." The Journal of Economic Perspectives (1999).

Sterling, P. and J. Eyer (1988). "Allostasis: A New Paradigm to Explain Arousal Pathology." Handbook of Life Stress, Cognition and Health. S. Fisher and J. Reason. New York, John Wiley \& Sons: 629-649.

Strully, Kate W. (2009) "Job Loss and Health in the U.S. Labor Market." Demography, 46:2, 221-246.

Sullivan, Daniel, and Till von Wachter. "Job Displacement and Mortality: An Analysis Using Administrative Data." The Quarterly Journal of Economics 124, no. 3 (August 1, 2009): 1265-1306. doi:10.1162/qjec.2009.124.3.1265.

Voydanoff, Patricia. 1984. "Economic Distress and Families: Policy Issues." Journal of Family Issues 5:273-88. 


\section{Figures}

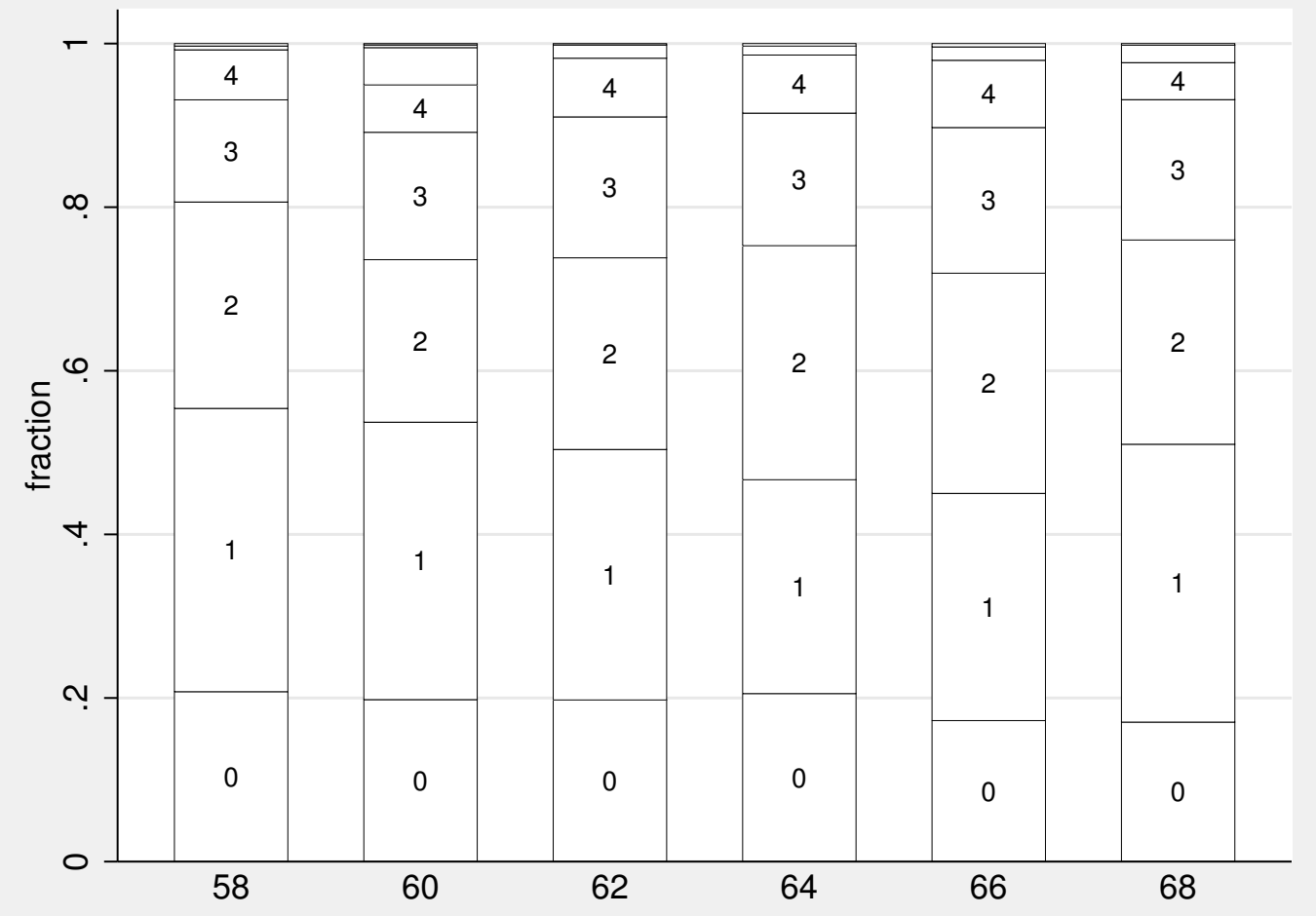

Figure 1: Distribution of the Count of High Risk Markers by Age: Each bar gives the distribution of the number of high risk markers and sums to one within each 5-year age group. Sample weights used. 


\section{Tables}

\begin{tabular}{lccc}
\hline & Threshold & Fraction & $\mathrm{N}$ \\
\hline High A1c & $>6.4 \%$ & 0.149 & 4602 \\
High C-reactive protein & $>3 \mathrm{mg} / \mathrm{L}$ & 0.394 & 4471 \\
High Cystatin C & $>1.55 \mathrm{mg} / \mathrm{L}$ & 0.058 & 4436 \\
High total cholesterol & $>240 \mathrm{mg} / \mathrm{L}$ & 0.207 & 4406 \\
High diastolic blood pressure & $>90 \mathrm{mmHg}$ & 0.192 & 4521 \\
High systolic blood pressure & $>140 \mathrm{mmHg}$ & 0.289 & 4521 \\
High pulse over 60 seconds & $>90$ & 0.057 & 4521 \\
Low HDL & $<40 \mathrm{mg} / \mathrm{L}$ & 0.198 & 3854 \\
Low total cholesterol & $<160 \mathrm{mg} / \mathrm{L}$ & 0.136 & 4406 \\
Low diastolic blood pressure & $<60 \mathrm{mmHg}$ & 0.024 & 4521 \\
\hline
\end{tabular}

Table 1: Definition of High Risk Markers from Biomarkers and Anthropometric Measures: Sample weights used. The number of observations varies across variables because of missing values. 


\begin{tabular}{lcccccc}
\hline & \multicolumn{3}{c}{ Ever had layoff } & \multicolumn{3}{c}{ Ever had bus. closed } \\
& No & Yes & T-test & No & Yes & T-test \\
\hline Count of risk markers & 1.660 & 1.797 & 2.338 & 1.675 & 1.764 & 1.143 \\
High lv. of A1c & 0.138 & 0.155 & 1.026 & 0.139 & 0.160 & 0.955 \\
High lv. of CRP & 0.393 & 0.422 & 1.301 & 0.395 & 0.435 & 1.340 \\
High lv, of Cystatin C & 0.055 & 0.047 & -0.753 & 0.055 & 0.041 & -1.029 \\
High total cholesterol & 0.218 & 0.230 & 0.658 & 0.220 & 0.219 & -0.030 \\
High diastolic BP & 0.190 & 0.207 & 0.935 & 0.192 & 0.202 & 0.405 \\
High systolic BP. & 0.284 & 0.300 & 0.779 & 0.283 & 0.320 & 1.318 \\
High pulse over 60 sec. & 0.054 & 0.067 & 1.242 & 0.056 & 0.063 & 0.491 \\
Low lv. of HDL & 0.189 & 0.218 & 1.601 & 0.195 & 0.184 & -0.461 \\
Low total cholesterol & 0.114 & 0.130 & 1.060 & 0.116 & 0.124 & 0.395 \\
Low diastolic BP & 0.024 & 0.021 & -0.510 & 0.024 & 0.019 & -0.590 \\
Diabetes & 0.194 & 0.180 & -0.785 & 0.194 & 0.163 & -1.285 \\
Hypertension & 0.536 & 0.574 & 1.657 & 0.540 & 0.562 & 0.706 \\
Heart disease & 0.210 & 0.188 & -1.204 & 0.207 & 0.203 & -0.134 \\
Stroke & 0.064 & 0.054 & -0.966 & 0.064 & 0.044 & -1.383 \\
Cancer & 0.126 & 0.143 & 1.134 & 0.130 & 0.115 & -0.719 \\
Lung disease & 0.098 & 0.107 & 0.698 & 0.098 & 0.113 & 0.840 \\
Died & 0.027 & 0.028 & 0.153 & 0.026 & 0.038 & 1.274 \\
\hline Observations & 3022 & 618 & & 3314 & 326 & \\
\hline
\end{tabular}

Table 2: Differences in Health Outcomes by Incidence of Layoff and Business Closed Since the First Interview: Sample weights used. CRP: C-reactive protein, BP: blood pressure, HDL: high-density lipoprotein. T statistics based on weighted regressions. 


\begin{tabular}{lcccccc}
\hline & \multicolumn{3}{c}{ Ever had layoff } & \multicolumn{3}{c}{ Ever had business closed } \\
& No & Yes & T-test & No & Yes & T-test \\
\hline Age & 63.99 & 64.48 & 3.633 & 64.02 & 64.64 & 3.528 \\
Male & 0.471 & 0.469 & -0.129 & 0.471 & 0.474 & 0.118 \\
High school & 0.597 & 0.574 & -1.183 & 0.589 & 0.644 & 2.103 \\
College & 0.255 & 0.248 & -0.402 & 0.262 & 0.166 & -4.156 \\
Black & 0.096 & 0.070 & -2.184 & 0.093 & 0.084 & -0.580 \\
Hispanic & 0.069 & 0.082 & 1.200 & 0.068 & 0.110 & 3.083 \\
Mother worked & 0.549 & 0.587 & 1.472 & 0.546 & 0.652 & 3.148 \\
\# inf. in child & 1.468 & 1.376 & -1.705 & 1.456 & 1.428 & -0.407 \\
Child health v.good & 0.804 & 0.824 & 1.024 & 0.806 & 0.819 & 0.502 \\
\# health cond. & 0.348 & 0.354 & 0.185 & 0.356 & 0.269 & -2.070 \\
1+ parent smoke & 0.703 & 0.738 & 1.541 & 0.709 & 0.708 & -0.033 \\
\# of marriage & 1.389 & 1.406 & 0.573 & 1.385 & 1.467 & 2.090 \\
\# of children & 2.580 & 2.546 & -0.518 & 2.577 & 2.549 & -0.330 \\
Age first child & 24.21 & 24.41 & 0.99 & 24.28 & 23.78 & -1.93 \\
Mother education & 10.30 & 10.44 & 0.886 & 10.35 & 9.992 & -1.783 \\
Father education & 9.918 & 10.027 & 0.640 & 9.964 & 9.615 & -1.552 \\
Primary industry & 0.081 & 0.091 & 0.835 & 0.084 & 0.071 & -0.832 \\
Secondary industry & 0.301 & 0.354 & 2.758 & 0.300 & 0.410 & 4.351 \\
Tertiary industry & 0.618 & 0.555 & -3.083 & 0.617 & 0.519 & -3.647 \\
Manual occupation & 0.283 & 0.285 & 0.082 & 0.277 & 0.355 & 3.141 \\
\hline
\end{tabular}

Table 3: Differences in Socio-Economic Characteristics by Incidence of Layoff and Business Closed Since First Interview: Sample weights used. In the sample, when restricting to those with non-missing information, we have 3,562 observations with 600 layoff and 318 business closed 


\begin{tabular}{|c|c|c|c|c|}
\hline Variable & (1) & $(2)$ & (3) & (4) \\
\hline Ever had layoff & $\begin{array}{c}0.169^{* * *} \\
(0.0577)\end{array}$ & $\begin{array}{c}0.167 * * * \\
(0.0578)\end{array}$ & $\begin{array}{c}0.170 * * * \\
(0.0578)\end{array}$ & $\begin{array}{c}0.167 * * * \\
(0.0579)\end{array}$ \\
\hline Ever had business closed & $\begin{array}{l}-0.0789 \\
(0.0788)\end{array}$ & $\begin{array}{l}-0.0791 \\
(0.0788)\end{array}$ & $\begin{array}{l}-0.0839 \\
(0.0789)\end{array}$ & $\begin{array}{l}-0.0841 \\
(0.0789)\end{array}$ \\
\hline Age in years & $\begin{array}{l}-0.0139 \\
(0.00856)\end{array}$ & $\begin{array}{l}-0.0167^{*} \\
(0.00871)\end{array}$ & $\begin{array}{l}-0.0159^{*} \\
(0.00863)\end{array}$ & $\begin{array}{r}-0.0184^{* *} \\
(0.00877)\end{array}$ \\
\hline Respondent is male & $\begin{array}{l}0.228^{* * *} \\
(0.0518)\end{array}$ & $\begin{array}{c}0.220^{* * *} \\
(0.0532)\end{array}$ & $\begin{array}{l}0.233^{* * *} \\
(0.0520)\end{array}$ & $\begin{array}{l}0.223^{* * *} \\
(0.0534)\end{array}$ \\
\hline Black & $\begin{array}{l}0.439^{* * *} \\
(0.0618)\end{array}$ & $\begin{array}{c}0.430^{* * *} \\
(0.0628)\end{array}$ & $\begin{array}{c}0.387^{* * *} \\
(0.0649)\end{array}$ & $\begin{array}{c}0.381^{* * * *} \\
(0.0658)\end{array}$ \\
\hline Hispanic & $\begin{array}{c}0.137^{*} \\
(0.0805)\end{array}$ & $\begin{array}{c}0.107 \\
(0.0823)\end{array}$ & $\begin{array}{c}0.0509 \\
(0.0867)\end{array}$ & $\begin{array}{c}0.0260 \\
(0.0882)\end{array}$ \\
\hline High school & $\begin{array}{r}-0.206^{* * *} \\
(0.0675)\end{array}$ & $\begin{array}{c}-0.195^{* * *} \\
(0.0682)\end{array}$ & $\begin{array}{l}-0.121^{*} \\
(0.0690)\end{array}$ & $\begin{array}{l}-0.113 \\
(0.0696)\end{array}$ \\
\hline College & $\begin{array}{c}-0.542^{* * *} \\
(0.0798)\end{array}$ & $\begin{array}{c}-0.528^{* * *} \\
(0.0825)\end{array}$ & $\begin{array}{c}-0.400^{* * *} \\
(0.0867)\end{array}$ & $\begin{array}{c}-0.391^{* * *} \\
(0.0888)\end{array}$ \\
\hline Manual occupation & $\begin{array}{c}-0.000870 \\
(0.0653)\end{array}$ & $\begin{array}{l}-0.00413 \\
(0.0654)\end{array}$ & $\begin{array}{l}-0.0279 \\
(0.0658)\end{array}$ & $\begin{array}{l}-0.0305 \\
(0.0659)\end{array}$ \\
\hline Employed at first obs. & $\begin{array}{l}-0.116^{* *} \\
(0.0513)\end{array}$ & $\begin{array}{l}-0.114^{* *} \\
(0.0514)\end{array}$ & $\begin{array}{l}-0.108^{* *} \\
(0.0515)\end{array}$ & $\begin{array}{l}-0.106^{* *} \\
(0.0516)\end{array}$ \\
\hline Mother worked & & & $\begin{array}{c}0.0187 \\
(0.0457)\end{array}$ & $\begin{array}{c}0.0174 \\
(0.0457)\end{array}$ \\
\hline $1+$ parent smoke $($ miss $=0)$ & & & $\begin{array}{c}0.0211 \\
(0.0373)\end{array}$ & $\begin{array}{l}0.0235 \\
(0.0373)\end{array}$ \\
\hline Mother education & & & $\begin{array}{r}-0.000932 \\
(0.00865)\end{array}$ & $\begin{array}{r}-0.000462 \\
(0.00864)\end{array}$ \\
\hline Father education & & & $\begin{array}{c}-0.0226^{* * *} \\
(0.00791)\end{array}$ & $\begin{array}{c}-0.0227^{* * *} \\
(0.00791)\end{array}$ \\
\hline Number of marriages & & $\begin{array}{c}0.0201 \\
(0.0295)\end{array}$ & & $\begin{array}{c}0.0225 \\
(0.0296)\end{array}$ \\
\hline Number of children & & $\begin{array}{c}0.0361^{* *} \\
(0.0161)\end{array}$ & & $\begin{array}{c}0.0332 * * \\
(0.0162)\end{array}$ \\
\hline Age first child & & $\begin{array}{c}0.00628 \\
(0.00527)\end{array}$ & & $\begin{array}{c}0.00651 \\
(0.00528)\end{array}$ \\
\hline Control health in childhood & no & no & yes & yes \\
\hline Control for indus. and occ. & yes & yes & yes & yes \\
\hline Observations & 3,562 & 3,562 & 3,562 & 3,562 \\
\hline
\end{tabular}

Table 4: Poisson Models of the Effect of Job Loss on Health Outcomes: The dependent variable is the count of high risk markers. Estimation is performed by maximum likelihood. Marginal effects on the count of high risk markers along with standard errors (in parenthesis) are reported. ${ }^{* * *} p<0.01,{ }^{* *} p<0.05,{ }^{*} p<0.1$. Dummy variables for missing information have been added for childhood variables, occupation and industry and age of the first child. The number of observations is voluntarily kept constant across columns 


\begin{tabular}{lcccc}
\hline Variables & $(1)$ & $(2)$ & $(3)$ & $(4)$ \\
\hline \multirow{3}{*}{ Ever had layoff } & & & & \\
& $0.167^{* * *}$ & $0.154^{* * *}$ & $0.195^{* * *}$ & -0.00856 \\
Ever had business closed & $(0.0579)$ & $(0.0579)$ & $(0.0670)$ & $(0.0463)$ \\
& -0.0841 & -0.103 & -0.117 & $-0.116^{*}$ \\
Household income in 1000\$ & $(0.0789)$ & $(0.0789)$ & $(0.0877)$ & $(0.0612)$ \\
& & -0.000496 & -0.000393 & $-0.00106^{* *}$ \\
Household net wealth in 1000\$ & & $(0.000522)$ & $(0.000589)$ & $(0.000420)$ \\
& & $-0.000612^{* * *}$ & $-0.000591^{* * *}$ & $-0.000487^{* * *}$ \\
& & $(8.68 \mathrm{e}-05)$ & $(9.86 \mathrm{e}-05)$ & $(6.72 \mathrm{e}-05)$ \\
\hline Observations & 3,562 & & \\
\hline
\end{tabular}

Table 5: Alternative Poisson Models of the Effect of Job Loss on Health Outcomes : The dependent variable is the count of risk markers for the first three specifications and the count of self-reported health conditions for the last one. The third specification is restricted to the sample of respondents who are employed at the first observation. Estimation by maximum likelihood. Marginal effects along with standard errors (in parenthesis). *** $p<0.01$, ** $p<0.05,{ }^{*} p<0.1$. Same control as in the last column of Table 4 are included in all specifications. 


\begin{tabular}{lcc}
\hline Model & Layoff & Business closure \\
\hline Count of risk markers & $-0.01055^{*}$ & 0.00083 \\
& $(0.0056)$ & $(0.0030)$ \\
More than two risk markers & $-0.02625^{* *}$ & -0.00940 \\
& $(0.0131)$ & $(0.0088)$ \\
Count of health conditions & -0.00740 & 0.00202 \\
More than one health condition & $(0.0055)$ & $(0.0034)$ \\
& -0.01843 & 0.00471 \\
& $(0.0126)$ & $(0.0080)$ \\
\hline
\end{tabular}

Table 6: Assessment of Reverse Causality: Estimates by maximum likelihood of the effect of each health measure on the probability of a layoff or business closure at the following interview. Marginal effects along with standard errors (in parenthesis). ${ }^{* * *} p<0.01$, ** $p<0.05,{ }^{*} p<0.1$. Separate logit regressions have been performed for each job lost type and for each variables of health. The health variable is the count of the following health problems: diabetes, hypertension, heart disease, stroke, cancer, lung disease. Controls are the same as in the main specification in column 4 of Table 4 


\begin{tabular}{|c|c|c|}
\hline & Layoff & Business closure \\
\hline Count of risk markers & $\begin{array}{c}0.2366^{* *} \\
(0.0773)\end{array}$ & $\begin{array}{l}-0.1494 \\
(0.1122)\end{array}$ \\
\hline \multicolumn{3}{|l|}{ By markers } \\
\hline High level of A1c & $\begin{array}{c}0.0448^{* *} \\
(0.0185)\end{array}$ & $\begin{array}{l}-0.0071 \\
(0.0251)\end{array}$ \\
\hline High level of C-reactive protein & $\begin{array}{c}0.0701^{* * *} \\
(0.0269)\end{array}$ & $\begin{array}{l}-0.0286 \\
(0.0365)\end{array}$ \\
\hline High level of Cystatin $\mathrm{C}$ & $\begin{array}{c}0.0015 \\
(0.0119)\end{array}$ & $\begin{array}{c}0.0078 \\
(0.0178)\end{array}$ \\
\hline High total cholesterol & $\begin{array}{c}0.0099 \\
(0.0221)\end{array}$ & $\begin{array}{c}0.0380 \\
(0.0304)\end{array}$ \\
\hline High diastolic blood pressure & $\begin{array}{c}0.0049 \\
(0.0214)\end{array}$ & $\begin{array}{c}0.0261 \\
(0.0297)\end{array}$ \\
\hline High systolic blood pressure & $\begin{array}{c}0.0087 \\
(0.0250)\end{array}$ & $\begin{array}{c}0.0276 \\
(0.0349)\end{array}$ \\
\hline High pulse over 60 seconds & $\begin{array}{c}0.0157 \\
(0.0127)\end{array}$ & $\begin{array}{c}0.0229 \\
(0.0185)\end{array}$ \\
\hline Low level of HDL & $\begin{array}{c}0.0490 \\
(0.0227)\end{array}$ & $\begin{array}{l}-0.0510 \\
(0.0318)\end{array}$ \\
\hline Low total cholesterol & $\begin{array}{l}0.0391 * \\
(0.0193)\end{array}$ & $\begin{array}{c}-0.0289 \\
(0.0298)\end{array}$ \\
\hline Low diastolic blood pressure & $\begin{array}{l}-0.0104 \\
(0.0096)\end{array}$ & $\begin{array}{c}0.0121 \\
(0.0118)\end{array}$ \\
\hline Count of health condition & $\begin{array}{c}0.1032^{* *} \\
(0.0476)\end{array}$ & $\begin{array}{l}-0.0630 \\
(0.0697)\end{array}$ \\
\hline More than one health condition & $\begin{array}{c}0.0025 \\
(0.0029) \\
\end{array}$ & $\begin{array}{c}0.0015 \\
(0.0052) \\
\end{array}$ \\
\hline Observation (control + treated) & 1130 & 586 \\
\hline
\end{tabular}

Table 7: Matching Estimates of the Effect of Job Loss on Health Outcomes : Estimation using the nearest-neighbor matching estimator (NNM) with one neighbour by treated observation. The average of the difference between the observed and matched observation along with standard errors ( in parenthesis) is reported. ${ }^{* * *} p<0.01,{ }^{* *} p<0.05,{ }^{*} p<0.1$. The match is done exactly by wave, and by the nearest-neighbor on a propensity score. The propensity score is obtained using a logit regression with the same set of variables as those used in Table 4 and in which we add variable health condition. Finally we add the health variables directly to the NNM matching set to obtain a better match on these variables. 


\begin{tabular}{lcc}
\hline & Layoff & Bussiness closure \\
\hline Regulary take drugs & 0.0048 & 0.0283 \\
& $(0.0180)$ & $(0.0274)$ \\
Doctors visits & $1.4577^{* * *}$ & -0.4126 \\
& $(0.5250)$ & $(0.7304)$ \\
$6+$ Doctors visits & -0.0068 & 0.0391 \\
& $(0.0264)$ & $(0.0349)$ \\
Num. night hosp & -0.6317 & 1.1246 \\
& $(0.4968)$ & $(0.7770)$ \\
$1+$ night hosp & 0.0132 & 0.0070 \\
& $(0.0227)$ & $(0.0297)$ \\
Observation (control + treated) & 1412 & 768 \\
\hline
\end{tabular}

Table 8: Matching Estimates of the Effect of Job Loss on Health Care Use : Estimation using the nearest-neighbor matching estimator (NNM) with one neighbour by treated observation. The average of the difference between the observed and matched observation along with standard errors ( in parenthesis) is reported. ${ }^{* * *} p<0.01,{ }^{* *} p<0.05,{ }^{*} p<0.1$. The match is done exactly by wave, and by the nearest-neighbor on a propensity score. The propensity score is obtained using a logit regression with the same set of variables as those used in Table 4 and in which we add variable health condition. Finally we add the health variables directly to the NNM matching set to obtain a better match on these variables. 


\section{Appendix}

\begin{tabular}{rc}
\hline & Observations \\
\hline Had bio-markers information in 2006/2008 & $\mathbf{1 3 0 6 4}$ \\
Cohort HRS & 6507 \\
Cohort Warbabies & 1668 \\
Total HRS-Warbabies & $\mathbf{8 1 7 5}$ \\
Age: $59-70$ in 2006/2008 & $\mathbf{4 7 4 7}$ \\
Had information on all bio-makers & $\mathbf{3 7 2 4}$ \\
Complete record for regression analysis & $\mathbf{3 5 6 2}$ \\
\hline
\end{tabular}

Table A.1: Summary of Sample selection 


\begin{tabular}{lcccccc}
\hline Count of risk markers & Age 58 & Age 60 & Age 62 & Age 64 & Age 66 & Age 68 \\
\hline 0 & 20.77 & 19.80 & 19.76 & 20.54 & 17.24 & 17.05 \\
1 & 34.63 & 33.91 & 30.62 & 26.14 & 27.77 & 33.97 \\
2 & 25.23 & 19.86 & 23.43 & 28.61 & 26.92 & 24.97 \\
3 & 12.49 & 15.58 & 17.23 & 16.21 & 17.81 & 17.16 \\
4 & 6.11 & 5.79 & 7.18 & 7.10 & 8.22 & 4.53 \\
5 & 0.47 & 4.56 & 1.62 & 1.10 & 1.63 & 2.13 \\
6 & 0.30 & 0.33 & 0.17 & 0.31 & 0.41 & 0.20 \\
7 & 0.00 & 0.17 & 0.00 & 0.00 & 0.00 & 0.00 \\
\hline
\end{tabular}

Table A.2: Percent Distribution of the Count of High Risk Markers by Age. Sample weights used. Data used in constructing Figure 1. 


\begin{tabular}{|c|c|c|c|c|}
\hline & \multicolumn{2}{|c|}{ Layoff } & \multicolumn{2}{|c|}{ Business closed } \\
\hline & Not matched & Matched & Not matched & Matched \\
\hline Heart disease & $11.89 \%$ & $0.00 \%$ & $12.19 \%$ & $0.00 \%$ \\
\hline Diabetes & $10.88 \%$ & $0.00 \%$ & $21.57 \%$ & $0.00 \%$ \\
\hline Stroke & $9.37 \%$ & $0.00 \%$ & $9.99 \%$ & $0.00 \%$ \\
\hline Hypertension & $2.54 \%$ & $0.00 \%$ & $14.01 \%$ & $-0.75 \%$ \\
\hline Cancer & $5.70 \%$ & $0.00 \%$ & $8.09 \%$ & $0.00 \%$ \\
\hline Lung disease & $-0.40 \%$ & $0.00 \%$ & $-0.06 \%$ & $0.00 \%$ \\
\hline Age & $22.17 \%$ & $4.65 \%$ & $25.85 \%$ & $1.54 \%$ \\
\hline Male & $-2.77 \%$ & $9.66 \%$ & $4.04 \%$ & $-4.26 \%$ \\
\hline Less than high school & $1.76 \%$ & $-0.45 \%$ & $-8.94 \%$ & $0.00 \%$ \\
\hline High school & $1.14 \%$ & $2.89 \%$ & $-9.42 \%$ & $4.29 \%$ \\
\hline College & $-3.07 \%$ & $-3.03 \%$ & $21.95 \%$ & $-6.31 \%$ \\
\hline Black & $8.06 \%$ & $-5.19 \%$ & $4.57 \%$ & $-1.04 \%$ \\
\hline Hispanic & $-1.00 \%$ & $3.02 \%$ & $-7.45 \%$ & $5.29 \%$ \\
\hline Mother worked & $-6.11 \%$ & $-5.36 \%$ & $-7.04 \%$ & $-2.07 \%$ \\
\hline \# inf. in child & $4.20 \%$ & $1.09 \%$ & $0.33 \%$ & $5.37 \%$ \\
\hline \# health cond. & $-0.73 \%$ & $1.32 \%$ & $3.58 \%$ & $-0.97 \%$ \\
\hline $1+$ parent smoke & $-5.07 \%$ & $-0.24 \%$ & $-4.19 \%$ & $4.64 \%$ \\
\hline Child health v.good & $-1.30 \%$ & $-1.06 \%$ & $-0.89 \%$ & $8.94 \%$ \\
\hline Child info. Missing & $-2.41 \%$ & $1.49 \%$ & $1.03 \%$ & $-11.99 \%$ \\
\hline Mother education & $-0.60 \%$ & $-4.21 \%$ & $19.03 \%$ & $-2.25 \%$ \\
\hline Father education & $-0.90 \%$ & $-2.63 \%$ & $13.55 \%$ & $-6.07 \%$ \\
\hline \# of marriage & $-6.03 \%$ & $-3.02 \%$ & $-3.53 \%$ & $4.47 \%$ \\
\hline \# of children & $-1.41 \%$ & $2.48 \%$ & $-3.15 \%$ & $-5.83 \%$ \\
\hline Age first child & $-4.08 \%$ & $0.27 \%$ & $11.48 \%$ & $8.62 \%$ \\
\hline Manual occupation & $-5.61 \%$ & $2.74 \%$ & $-14.33 \%$ & $-11.26 \%$ \\
\hline Occupation missing & $4.81 \%$ & $1.38 \%$ & $16.91 \%$ & $12.02 \%$ \\
\hline Primary industry & $-2.49 \%$ & $-0.47 \%$ & $15.26 \%$ & $12.19 \%$ \\
\hline Secondary industry & $-14.26 \%$ & $9.59 \%$ & $-24.98 \%$ & $-4.22 \%$ \\
\hline Tertiary industry & $14.99 \%$ & $-8.86 \%$ & $12.93 \%$ & $-4.09 \%$ \\
\hline Industry missing & $1.73 \%$ & $-1.97 \%$ & $17.12 \%$ & $7.62 \%$ \\
\hline Employed & $-19.08 \%$ & $-4.61 \%$ & $-53.31 \%$ & $-3.65 \%$ \\
\hline Observations & 1130 & & 586 & \\
\hline
\end{tabular}

Table A.3: Standard Bias Estimates from Matching: We compare a standardized difference in means before and after matching where $d=\left(\bar{x}_{\text {treatment }}-\bar{x}_{\text {control }}\right) / \sqrt{\left(s_{\text {treatment }}-s_{\text {control }}\right) / 2}$. 
Tél. : 514-985-4000 • Téléc. : 514-985-4039

www.cirano.qc.ca・info@cirano.qc.ca 